\title{
Perception of Social Media as a Source of Relevant Information
}

\author{
Tihomir Vranešević * \\ Nenad Peric ${ }^{*}$ \\ Tajana Marušićc***
}

\begin{abstract}
Social media today represent a global community of different nationalities - the size of China in terms of population, and social networking sites are online venues where users can create and post content. Social networks have also become one of the most popular ways for people to socialize, connect with friends and family, purchase items and gather relevant information about current and political topics and views. The most popular and biggest social network is Facebook and its influence in every pore of our society is evident, e.g. potential misuse of its user's data in different purpose including manipulation in political purposes. This paper will also cover the findings of a survey conducted in Croatia and Serbia about the perception of social media and social networks as a source of gathering relevant information.
\end{abstract}

Keywords: Social media; social network; perception; Croatia; Serbia

JEL Classification: M38

\section{Introduction}

In the last fifteen years, social media became the most used way of communication. Social networks such as Facebook, Instagram, Twitter (etc) and applications such as Whatsapp, Viber, and Messenger are now the way that people (mainly) communicate with each other. Social media and social networks are also the way that companies and brands communicate with their consumers, the way that newspapers publish their stories, etc. We turn to social networks for relevant information, to communicate with friends and families and we as a society practically live a virtual life on social

\footnotetext{
* Tihomir Vranešević is at Faculty of Economics and Business, University of Zagreb, Zagreb, Croatia.

** Nenad Perić is at Metropolitan University, Beograd, Serbia.

**** Tajana Marušić is at University North, Koprivnica, Croatia.
} 
media beside our real lives. The term social media implies internet services that facilitate social human contact (Paquette,2013).

A social network represents a free virtual space where users can share interests, information, experience, pictures, discuss different topics.

This paper will try to explain a theoretical framework of social media and social networks with the emphasis on the largest social network - Facebook and how it became what it is today in its brief history of fifteen years. It will also present results of a survey conducted on respondents in Croatia and Serbia, gathered through questions about social networks as a source of relevant information. Respondents were asked questions about how often they use social network; what social network they use the most when wanting to be informed; do they use blogs; if they believe that social networks contribute to the development of democracy, if they want to receive news of political content through social media; if they regularly receive news about political option they support through social networks; if they believe the information they receive through social media because they perceive them as less vulnerable to media censorship; if they use social networks to express personal political attitudes and beliefs; if social networks influence the formation of their political attitudes and belief; and if social networks affect their choice when voting. Answers to these questions will help define the respondent's perception about social networks, its impact on political topics, attitudes, and if they perceive social media as a source of relevant information.

\section{Theoretical Frame}

Social media is the environment in which social networking takes place and has altered the way in which consumers gather information and make buying decisions (Kaplan and Haenlein 2010). Kaplan and Haenlein (2010) also define social media as an Internet-based applications where users can create their profiles and share them with friends, family, colleagues. Social media today represents the global community of every nationality in the world estimated to be the size of China in terms of population. (www.brandba.se).

Social media sites also allow users to express a positive or negative opinion about many different topics such as health, politics, brands, etc. (Christodoulides, 2009).

Social networking sites are online venues where members can create and post content to profiles (i.e., lists of demographic information and personal interests constructed by completing forms within the site) and can form personal networks that connect them to others using tools embedded in the social software (Mazur, 2010). The term social media implies internet services that facilitate social human contact. There are different types of social networks such as Facebook, Twitter, Instagram, etc. Basic features necessary for a website to meet the requirements as a social net- 
work website: the site must contain user profiles, content, a method that permits users to connect with each other and post comments on each other's pages, and join virtual groups based on common interests such as fashion or politics (Paquette, 2013). After joining a social network site, users are prompted to identify others in the system with whom they have a relationship. The label for these relationships differs depending on the site-popular terms include "Friends," "Contacts," and "Fans."(Boyd, Ellison, 2008). Chu (2011) also found that users who are Facebook group members maintain a more favourable attitude toward social media and advertising.

A social network represents a free virtual space where users can share opinion, upload and download digital material such as photos, videos and so on discuss, chat, retrieve information, ask suggestions through several user-friendly tools, which allow keeping in touch with friends in a fast and easy way (Di Pietro, Pantano, 2012). Brands and companies use social media as a way to reach consumers and to offer a new way to buy products or services. (Shankar et al. 2011). Media of communication changed together with the audience that uses them (van Dijk \& Poell, 2013). Social networks such as Facebook also became platforms to exchange different relevant pieces of information since most of the daily newspapers and magazines share current news on their social network accounts. From 1991 became the „explosion” of platforms used for communication such as Blogger in 1999, Wikipedia in 2001, Myspace in 2003, Facebook and Flickr in 2004, Youtube in 2005, Twitter in 2006, some of them became so popular that using them invented new verbs for example „tweeting" is now a commonly used verb and describes writing on Twitter.

The social network that made the biggest impact by far is the introduction and rise of Facebook that has been one of the most important social trends of the past decade (Cears et al, 2012). Facebook is the most popular social media today and is the largest repository of personal information about humankind to ever existed (www.wired.com). This all happened in the last fifteen years. In this time Facebook became the most important social media in the world. Most people use Facebook to get instant communication and connection with their friends. Facebook changed the way hundreds of millions of people relate to one another and share information. (Cheung et al, 2011). It is an ongoing database of social activity with information being added in real time. Facebook in addition to reflecting existing social processes, is also spawning new ones by changing the way hundreds of millions of people relate to one another and share information (Wilson et al, 2013).

Facebook acquired or crushed most of its competition and today is used by onethird of the world's population. Its world domination began at Harvard University when today`s CEO and founder in 2003 created an online programme called Facemash. It was founded by Mark Zuckerberg who was at the time 19 years old. To this day there is controversy how Facebook was created and by who. In the fall of 2003, three Harvard seniors were looking for a web developer who would help them make a site that was to be called Harvardconnections.com. These three students were 
called Cameron and Tyler Winklevoss and Divya Narendra. They decided to ask Mark Zuckerberg, also a Harvard student who was already a „celebrity“ on Harvard for his Facemash program (www.bussinesinsider.com). He got into trouble for this programme because it worked in a way that it pulled photos of Harvard students off Harvard`s web site and students would vote who was more attractive. Zuckerberg was called before Harvard's disciplinary board for students. He was charged with breaching security, violating copyrights, and violating individual privacy (www.thecrimson. com ). All of these issues are still very much current 15 years later for Facebook. Harvard trio envisioned Harvardconnection.com to be a site for Harvard students only, and new users to register with Harvard.edu mail addresses, the next step would be to expand Harvard Connection to schools around the country. Mark Zuckerberg started programming and the rest is history and the beginning of a lawsuit by the Winklevoss twins and Divya Narendra claiming that Facebook site launched by Zuckerberg was based partly on their idea. In the end, they settled for more than 65 million dollars.

Companies official web page provides an overview of how Facebook developed from 2004 until 2018. Figure 1

Figure 1: Developmental timeline of Facebook important milestones

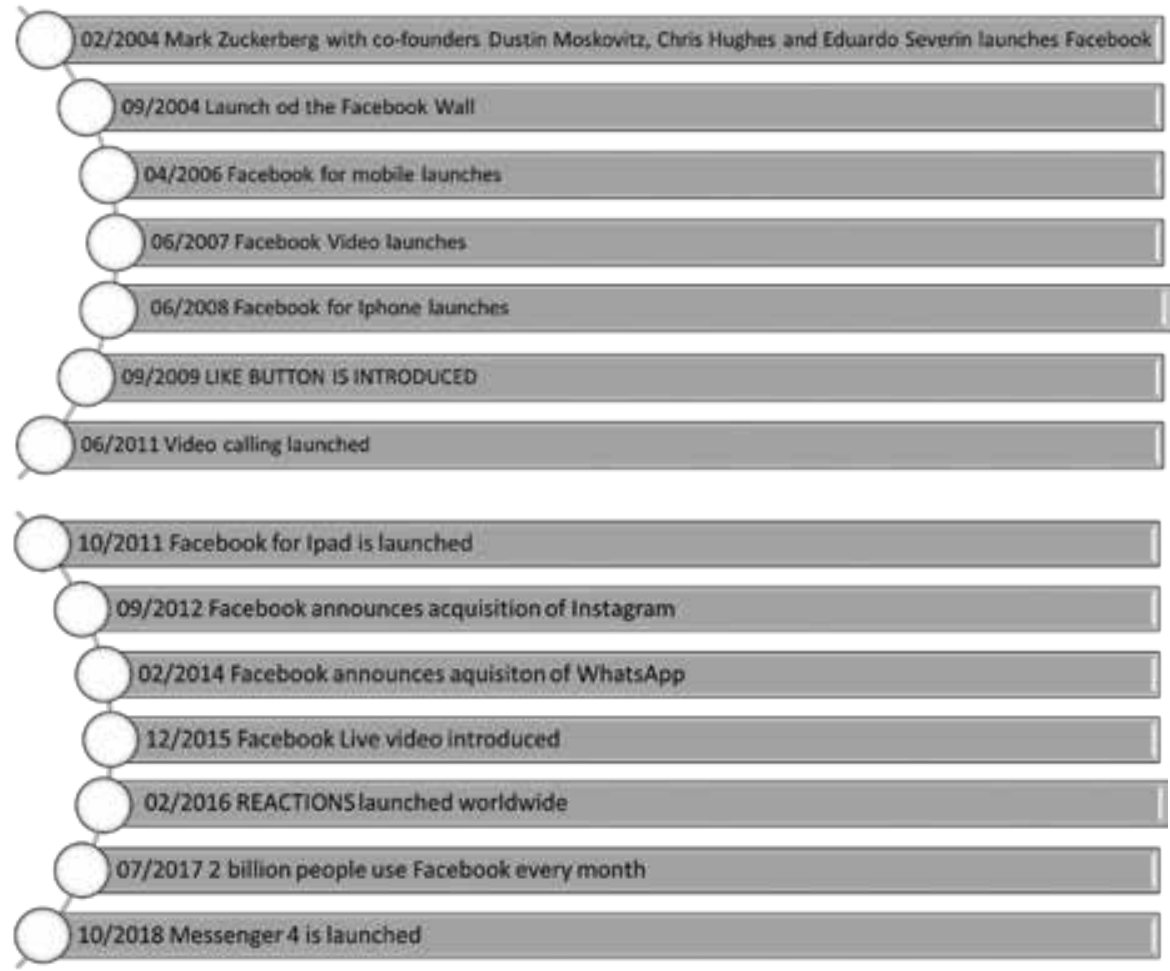

Source: authors, based on data retrieved April 11, 2019, from https://newsroom.fb.com/company-info/, 
Facebook is a social phenomenon that is and surely will be recorded as a milestone in the world's history. After the settlement with Winkelvoss twins and Dyvia Narendra, Facebook continued its growth and in 2012 reached the number of one-billion users. Parallel with that new startups emerged that were competing for people's screen time. One of such startups was Instagram which in the period from 2010 when it was launched until 2012 had more than 50 million users. These numbers were nothing compared to Facebook, but Mark Zuckerberg was talented not only for programming and building business empires but also for recognizing potential competitors who could become business acquisitions. Facebook bought Instagram in 2012 for 1,2 bn dollars, which is a small amount of money for a platform that 7 years later has 1 billion users. Facebook continued its global expansion by acquiring Whatsapp in 2014 for the amount of 19,3 bn dollars. Five years later Whatsapp went from 500 million users to 1,5 billion. Combined there are now more than 2,5 billion people using at least one messaging service or social network owned by Facebook (www.independent.co.uk). Increase in Facebook users is constant as well as is an increase in monthly active users worldwide, and it went from 1 million users in 2004 to 2,3 bn active monthly users in 2018 (www.ictbussines.com)

There are 7,6 billion people on Earth, and 4,2 billion uses the Internet, which means that more than half of all Internet users are on Facebook, or to be more exact $1 / 3$ of the world population is on Facebook (www.ictbussines.com) as seen in Figure 2.

Figure 2: Leading countries based on the number of Facebook users as of January 2019 (in million)

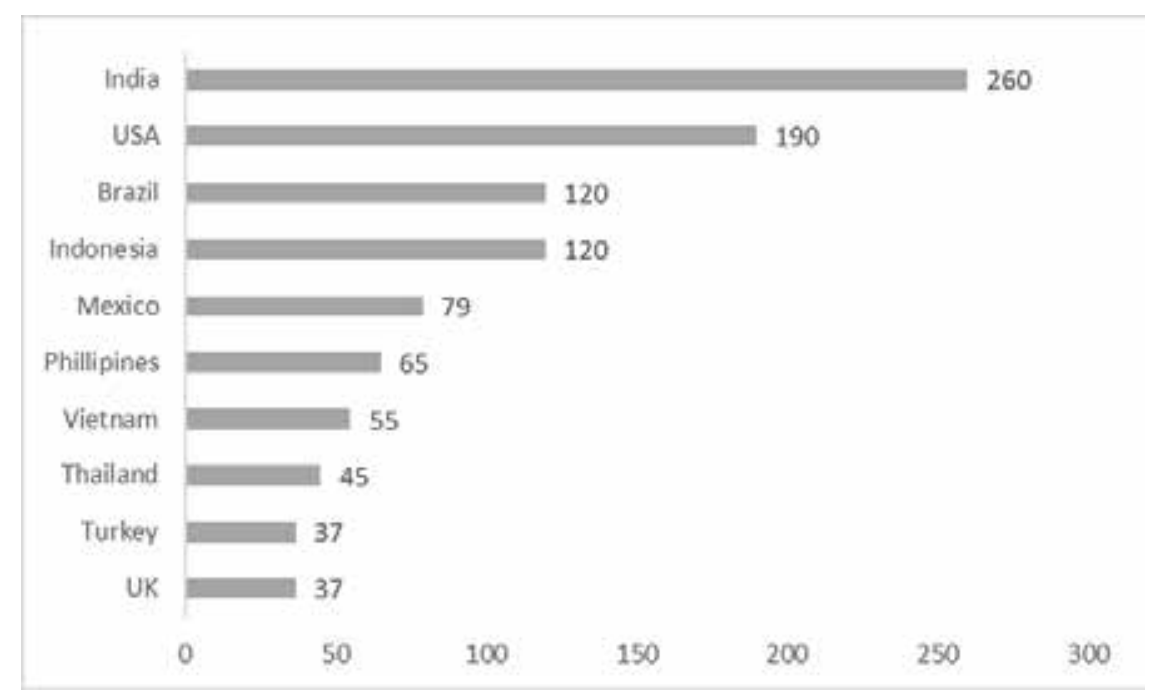

Source: https:/www.statista.com/statistics/268136/top-15-countries-based-on-number-of-facebook-users/, retrieved April 20, 2019 
The largest number of Facebook users is in India with 300 million users, the United States with 210 million users. The UK, on the other hand, is at the last place with 40 million users.

From an idea in a Harvard dorm room to probably the most influential company in the world, Facebook today has 35,587 employees worldwide, and in December 2018 there were 1,52 billion active daily users on Facebook. The company has twenty offices in America and 46 international offices(www.newsroom.fb.com). Mark Zuckerberg remains Chairman and CEO, as well as a founder of Facebook. The companies website states that Mark Zuckerberg is responsible for setting the overall direction and product strategy for the company, as well as the development of its core technology and infrastructure.

Besides using social networks for connecting with families friends and generally socializing, users use social media to read relevant information such as daily news, political topics, etc. Facebook`s impact on political issues such as elections in America when Donald Trump was elected was again another scandal regarding Facebook. This is known as the Cambridge Analytica scandal. Cambridge Analytica is a UK an political consulting agency which in 2014 was hired to build a psychographic profile of Americans to better target election messages for the Donald Trump presidential campaign. Cambridge Analytica decided to do it in a way that it harvested and misused data obtained from Facebook. Facebook has also been accused of blocking the ability of independent researchers to effectively study how political disinformation flows across its ad platform (ww.techchrunch.com). There is a constant talk that Facebook is misusing data it has on its users. Although Mark Zuckerberg continuously tries to ensure Facebook users that their data is safe, controversy is not quieting down. Eight international parliaments with lawmakers are forming a grand committee that wants to question Mark Zuckerberg about Facebook`s negative impact on democratic processes globally and a string of data misuse and security scandals linked to Facebook (ww.techchrunch.com). It will be very interesting to observe, and perhaps research further Facebook future path, regarding its size, privacy issues and undeniable influence it has on almost all aspects of its user's life. While researching the influence of social networks in general for this article, authors also wanted to research what respondents in Croatia and Serbia think of social networks as a channel of communication about political topics and happenings.

\section{Results and Analysis}

\section{Methodology}

A sample represented 213 respondents in Croatia and 232 respondents in Serbia. In Croatia the sample was structured as follows: $33,8 \%$ were male and $66,2 \%$ were women, $77,5 \%$ were employed, $3,3 \%$ were unemployed, $17,4 \%$ were students, $1,9 \%$ 
were retired. Also in Croatia the largest number of respondents $(21,1 \%)$ live in households with inbetween 1.501 to 2.000 euros of monthly income. In Serbia 42,1\% were male and 56,9\% were women, 55,2\% were employed, 5,2\% unemployed, $17,2 \%$ were students and $6,9 \%$ retired, also the largest number of respondents $(22,4 \%)$ live in households with monthly income inbetween 501 to 1.000 euros of.

This study was of a quantitative type and was carried out through a questionnaire that covered the socio-demographic data of the respondent in the first part of the question, while in the second part the group of dependent variables was operationalized through questions with closed responses and statements.

\section{Results}

By the use of dependent variables, respondents were asked about social media as a source of information about political topics. There is a difference in the frequency of using social media as a source of political information in Croatia and Serbia. In Croatia $72,8 \%$ of respondents use social media frequently, and in Serbia, 58,6\% use it frequently as seen in Figure 3.

Figure 3: Frequency of usage of social media - comparison Croatia and Serbia; answers: "frequently"

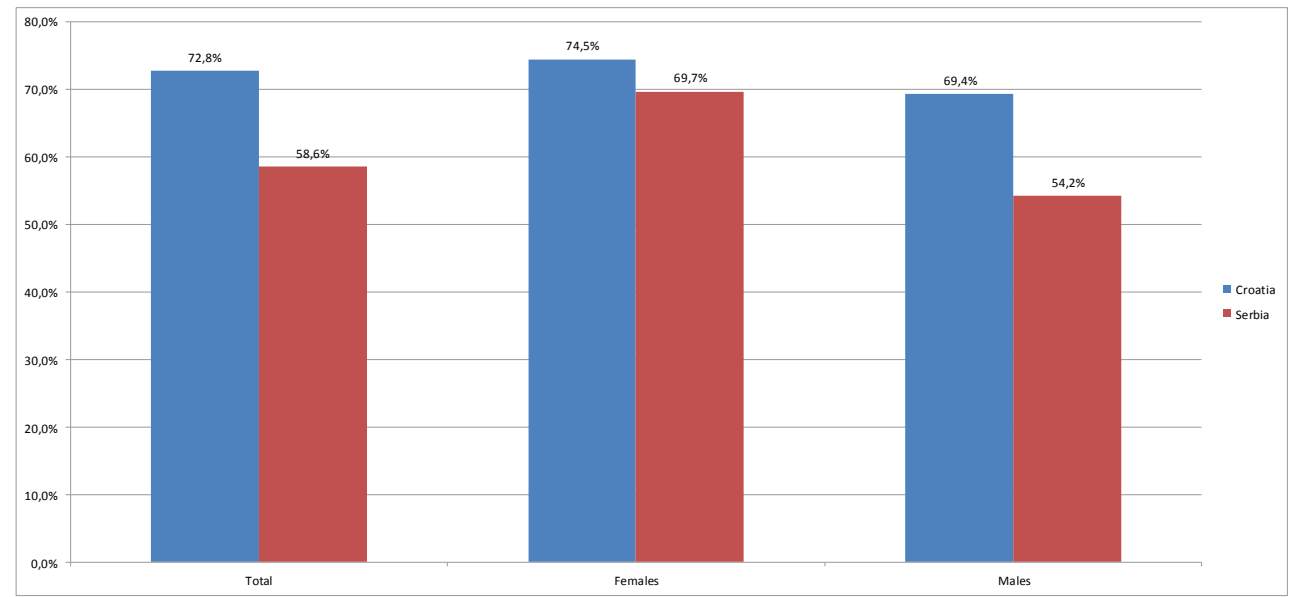

There is also a difference between the frequency of usage of social networks between women and men in Croatia and Serbia. Women use it frequently in Croatia $(74,51 \%)$ and in Serbia $(69,70 \%)$. The difference is visible between men also. In Croatia, $69,4 \%$ of questioned men use social media frequently while $54,2 \%$ in Serbia use it frequently. 
It was also important to determine why respondents use or do not use social media for gathering relevant information. Is it because more and more people get informed through social media, or is it that they do not use them because they think social media is not meant to use for political marketing, or perhaps they are not sure about social media and standard media. The highest percentage of respondents in Croatia $(60,1 \%)$ and Serbia $(58,6 \%)$ use and consider social networks as a source of relevant information as seen in Figure 4.

Figure 4. Do you use social networks as a source of relevant information?

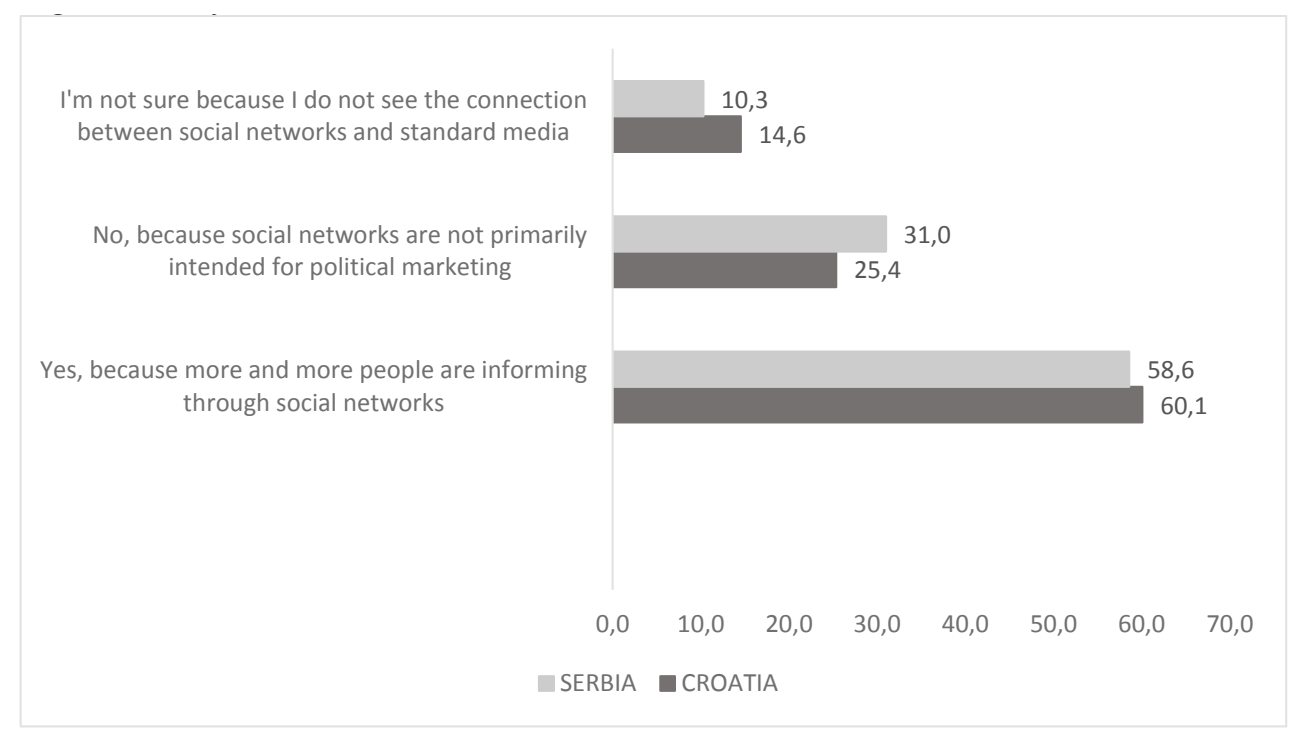

Respondents were also asked 12 question about receiving relevant information through social media. 12 claims were observed collectively and have average grades ranging from 1,85 to 3,35 on the scale from $1-5$ where $1=\mathrm{I}$ completely disagree, $2=$ I disagree, $3=\mathrm{I}$ am not sure, 4= I agree, 5= I completely agree. For being informed I use Facebook the most 3,35 for Croatia and 2,81 for Serbia, For being informed I use Twitter social network the most 1,46 vs 1,75; For being informed I usually use some other social network 2,50 vs 2,66; I follow blogs about political topics 2,38 vs 1,$89 ;$ I believe that social networks contribute to the development of democracy and improve the common life of different people 3,24 vs 2,97; It does not want to receive news and press releases of political content through social networks because it is a public display of my political commitment 2,93 vs 3,10; I regularly receive the news and announcements of the political option I support through social networks 2,15 vs 1,88; I believe the information I receive through social networks because I think they are less vulnerable to media censorship 2,84 vs 2,84 ; I use social networks to express personal political attitudes and beliefs 1,85 vs 2,07; Social networks influ- 
ence the formation of my personal political attitudes and belief 2,04 vs 2,14; Social networks affect my choice when voting 1,88vs 1,91. Results for the overall evaluation of receiving relevant information through social media is Croatia - mean 2,42 vs Serbia 2,37 as seen in Figure 5.

Figure 5: Mean (average value) of dimensions and overall evaluation of receiving relevant information through social media

\begin{tabular}{|l|c|c|c|}
\hline & CROATIA & SERBIA & DIFFERENCE \\
\hline For being informed I use Facebook the most. & 3,35 & 2,81 & 0,54 \\
\hline For being informed I use Twitter social network the most. & 1,46 & 1,75 & $-0,29$ \\
\hline For being informed i usually use some other social network & 2,50 & 2,66 & $-0,16$ \\
\hline I follow blogs about political topics & 2,38 & 1,89 & 0,49 \\
\hline $\begin{array}{l}\text { I believe that social networks contribute to the development of } \\
\text { democracy and improve the common life of different people }\end{array}$ & 3,24 & 2,97 & 0,27 \\
\hline $\begin{array}{l}\text { It do not want to receive news and press releases of political content } \\
\text { through social networks because it is a public display of my political } \\
\text { commitment }\end{array}$ & 2,93 & 3,10 & $-0,17$ \\
\hline $\begin{array}{l}\text { I regularly receive the news and announcements of the political } \\
\text { option I support through social networks }\end{array}$ & 2,15 & 1,88 & 0,27 \\
\hline $\begin{array}{l}\text { I believe the information I receive through social networks because } \\
\text { I think they are less vulnerable to media censorship }\end{array}$ & 2,84 & 2,84 & 0,00 \\
\hline I use social networks to express personal political attitudes and beliefs & 1,85 & 2,07 & $-0,22$ \\
\hline $\begin{array}{l}\text { Social networks influence the formation of my personal political } \\
\text { attitudes and belief }\end{array}$ & 2,04 & 2,14 & $-0,10$ \\
\hline Social networks affect my choice when voting & 1,88 & 1,91 & $-0,03$ \\
\hline Overall evaluation & 2,42 & 2,37 & 0,05 \\
\hline
\end{tabular}

In the claims value system, Croatia has somewhat better results in using social media for receiving relevant information. The biggest difference in Croatia's favor is in using Facebook the most for receiving relevant information, as well as following blogs about political topics, and the smallest difference is in believing that social networks contribute to the development of democracy and improve the common life of different people and regularly receiving the news and announcements of the political option I support through social network.

\section{Research limitations}

The limitations of the research could be primarily related to the size of the sample $\mathrm{n}=213$ for Croatia and 232 for Serbia. When analysing data it should be taken into account that the respondents in Croatia are mainly students (that are employed) where in Serbia there is a more diverse socially demographic sample. Although there are limitations to the research, we believe they are not significant to undermine obtained results. 


\section{Conclusion}

More than $70 \%$ of respondents in Croatia use social media regularly, as well as 59\% respondents in Serbia. There is also a difference in the usage of social media by gender. In Croatia $74,51 \%$ of women who participated in the survey use social media, while in Serbia it is $69,70 \%$ of women. In Croatia $69,4 \%$ of male reposndents use social media frequently, while in Serbia $54,2 \%$ use it ocasionally.

The aim of the survey also was to determine why respondents use or do not use social networks for gathering relevant information. Three answers were possible; Yes, because more and more people are informing themselves through social networks; No, because social networks are not primarily intended for political marketing; I am not sure because I do not see the connection between social networks and stnadard media 60,1\% of respondents in Croatia and 58,6\% in Serbia answered that they use social networks as a source of relevant information. 25,4\% of respondents in Croatia and 31,\% answered that they do not use social networks as a source of relevant information because they do not think that social networks are intended for political marketing. 14,6\% of respondents in Croatia and 10,3\% in Serbia are not sure because they do not see the connection between social networks and standard media.

It can be concluded that a high percentage of survey respondents in Croatia and Serbia use and consider social media as a source of relevant information.

Respondents were also asked 12 questions about receiving relevant information through social media. Results for the overall evaluation of receiving relevant information through social media is Croatia - mean 2,42 vs Serbia 2,37. Croatia has somewhat better results in using social media for receiving relevant information. The question that had the highest average grades and the biggest difference in values was For being informed I use Facebook the most 3,35 for Croatia and 2,81 for Serbia compared to For being informed I use Twitter the most 1,45 for Croatia vs 1,75 for Serbia where can be concluded that Facebook is prefered social network for respondents in Croatia and Serbia. Overall the biggest difference in Croatiàs favour is in using Facebook the most for receiving relevant information, as well as following blogs about political topics, and the smallest difference is in believing that social networks contribute to the development of democracy and improve the common life of different people and regularly receiving the news and announcements of the political option I support through social network.

A larger sample might get different results and thus this remains recommendation for further research. It would also be recommended to research privacy perception that respondents have of social networks. Do they think or notice that social networks present information that are visible to users based on their previous clicks and searches. Especially in corellation to relevant information they see on social media as well 
as advertising on those same platforms.. Does it have a positive or negative impact on their perception about social media and social networks.

We hope that results presented in this paper will encourage further research in the field of social media and social networks and their undeniable impact on user communication between themsleves and between brands, newspapers, political parties, etc, while continous disscusions about users data missuse and manipulation of information on social media continue to grow.

\section{REFERENCES}

Boyd, D.M, Ellison, N.B, (2008), Social network sites: Definition, history and scholarship, Journal od Computer_Mediated Communication 13, 210-230, DOI:10.1111/j.1083-6101.2007.00393.x

Caers R., De Feyter T., De Couck, M., Stough T., Vigna C., Du Bois C., (2013), Facebook: A literature review, New media \& society, 15(6), p. 982-1002. DOI/10.1177/1461444813488061

Cheung, C. M. K., Chiu, P. K . and Lee, M. K. O. ( 2011 ), Online social networks: Why do students use Facebook?, Computers in Human Behavior, Vol. 27, No. 4, pp. 1337 - 1343. DOI:10.1016/j. chb.2010.07.028

Christodulides, G., (2009), Branding in the post - Internet era. Marketing Theory, vol 9 (1), p. 141-144. DOI.org/10.1177/1470593108100071

Chu, Shu-Chuan. (2011), Viral advertising in social media: Participation in Facebook groups and responses among college-aged users, Journal of Interactive Advertising 12: 30-43. DOI: 10.1080/15252019.2011.10722189

Di Pietro, L., Pantano E., 2012. An Empirical Investigation of social network influence on consumer purchasing decision: The Case of Facebook." Journal of Direct Data and Digital Marketing Practice 14: 18-29. DOI: 10.1057/dddmp.2012.10

Kaplan, A., Haenlein, M. 2010, Users of the World, Unite! The Challenges and Opportunities of Social Media.” Business Horizons 53, p. 59-68. DOI:10.1016/j.bushor.2009.09.003

Paquette, H., (2013). Social Media as a Marketing Tool: A Literature Review, Major Papers by Master of Science Students. Paper 2. Retrieved April 25, 2019, from http://digitalcommons.uri.edu/ tmd_major_papers/2

Mazur, E. (2010). Collecting data from social networking Web sites and blogs. Advanced methods for conducting online behavioral research (pp. 77-90). Washington, DC, US: American Psychological Association: DOI.org/10.1037/12076-006

Shankar, V., Inman, J., Mantrala, M., Kelley, E., Rizley, R. (2011). Innovations in Shopper Marketing: Current Insights and Future Research Issues. Journal of Retailing 1, p.29-42. DOI:10.1016/j. jretai.2011.04.007

Van Dijck, J., Poell, T. (2013). Understanding Social Media Logic. Media and Communication, 1(1), p. 2-14. DOI.org/10.17645/mac.v1i1.70

Wilson, R.E., Gosling, S.D., Graham, L.T., (2012), A Review of Facebook Research in Social Sciences, Perspectives on Psychological Science 7(3), 203-220. DOI:10.1177/1745691612442904

Barr, S. (2018), When did Facebook start? The story behind a company that took over the world. Retrieved April 10, 2019, from https://www.independent.co.uk/life-style/gadgets-and-tech/facebook-when-started-how-mark-zuckerberg-history-harvard-eduardo-saverin-a8505151.html

Carlson N. (2010), At last - the full story of how Facebook was founded. Retrieved March 29, 2019, from https://www.businessinsider.com/how-facebook-was-founded-2010-3 
Kaplan K.A. (2003), Facemash creator survives ad bord. Retrieved April 10, 2019, from https://www. thecrimson.com/article/2003/11/19/facemash-creator-survives-ad-board-the/

Lomas, N.(2019), Facebook accused of blocking wider efforts to study its ad platform. Retrieved April 30, 2019, from https://techcrunch.com/2019/04/29/facebook-accused-of-blocking-wider-efforts-to-study-its-ad-platform/

Lomas, N. (2018), Now eight parliaments are demanding Zuckerberg answers for Facebook scandals. Retrieved April 20, 2019, from https://techcrunch.com/2018/11/19/now-eight-parliaments-are-demanding-zuckerberg-answers-for-facebook-scandals/

Martienau P., Matsakis L., (2019), All the times Facebook moved fast and sometimes broke things, Retrieved April 10, 2019, from https://www.wired.com/story/15-years-later-what-is-facebook/

Perić, M. (2019), Facebookov uzlet od 0 do 2,3 milijarde korisnika u 15 godina. Retrieved April 12, 2019 from https://www.ictbusiness.info/internet/infografika-facebookov-uzlet-od-0-do-2-3milijarde-korisnika-u-15-godina

Slatiel, S. (2015), Social Media Revolution: New Role of Consumers and Marketers. Retrieved April 20, 2019, from http://www.brandba.se/blog/2015/10/2/social-media-evolution-new-role-of-consumers-and-marketers

https://newsroom.fb.com/company-info/, retrieved April 11, 2019

https://www.statista.com/statistics/268136/top-15-countries-based-on-number-of-facebook-users/, retrieved April 11, 2019 